\title{
MODELLING AND PREDICTING THE EFFECTS OF PROCESS PARAMETERS FOR BEAD ON PLATE CHARACTERISTICS FOR SUBMERGED ARC WELDING OF HSLA STEEL
}

\section{SANDEEP JINDAL \& JAGDIP CHAUHAN}

Department of Mechanical Engineering, Guru Jambheshwar University of Science and Technology, Hisar, India

KEYWORDS: Submerged arc welding, HSLA steel, response surface methodology and central composite design

Received: Jul 07, 2020; Accepted: Aug 19, 2020; Published: Aug 25, 2020; Paper Id.: IJMPERDAUG202035

\section{INTRODUCTION}

Submerged arc welding (SAW) technique was developed to enhance productivity and to limit the welding costs in industries. In today scenario SAW is being used owing to its unmatched characteristics like conveniently controlled input parameters, sound weld, zero environmental contact, smooth and zero leakage welds [1], [2], [3]. Since oil/gas is to be transported over long distances so it is essential that pipeline material and welds should be strong enough to withstand the weight of the pipeline and oil/gas. Welding procedure should be suitably selected; one part of which involves selection of welding parameters during the laying of pipelines in oil and gas industries [4].

Parsad et al. [5] in their work studied the effect of current and speed on impact strength, microhardness and microstructures in submerged arc welding of micro alloyed steel welds. The cited work indicated that impact strength and microhardness were recorded to increase by increasing welding current for both fusion zone and heat affected zone (HAZ). Microhardness increased from centre of weld to portions away from weld centre. Prediction equations have been formed by Murugan et al. [6] for different weld bead geometry characteristics in the form of welding variables; arc voltage, weld speed, wire feed rate and nozzle to plate distance on steel plates with the help of response surface methodology designing technique.

Singh et al. [7] suggested that the mechanical properties of a weld joint are greatly influenced by the 
polarity, as it significantly affects the portion of heat transferred to electrode wire and work in the welding which further affects weld bead geometry parameters. Yadav et al. [8] did experimentation on $20 \mathrm{~mm}$ thick MS plates of size $90 \times 300 \mathrm{~mm}$ to make butt "V" joint; to study the characteristics of HAZ and thermal field, bead profile characteristics and fusion zones. The work assumed the oval shaped heat source model to depict the practically determined bead profile. The authors suggested that oval shaped model may be used for finding the temporal temperature distribution, HAZ spread and weld bead profile of the welded plate in SAW.

The effect of SAW process variables on the assessment of HAZ for submerged arc welding has been studied by Lee et al. [9]. It was suggested from the work that an efficient fusion welding technique is that where a most of the amount of input heat is utilized in fusing the welding wire/base metal and very less amount of heat is dissipated in forming the HAZ especially in materials with high-strength and higher toughness.

In the present work; empirical equations are formulated to analyzing the effect of SAW input variables for reinforcement area (RA), penetration area (PA) and dilution.

\section{EXPERIMENTAL DESIGN AND PERFORMING EXPERIMENTS}

Experimental design: CCD model of response surface methodology (RSM) is utilized [10], [11], [12] for designing the experiments taking three factor with five level. RSM utilizes mathematical and statistical methods for empirical modelling with an objective to optimize output variable affected by input variables. The CCD is a well-structured statistical design which includes first-order $(2 \mathrm{~N})$ designs augmented by additional centre and axial points to allow estimation of the output responses of a second-order model with $\mathrm{N}$ factors. In general, the central composite design consists of factorial runs, $\mathrm{nf}=$ $2 \mathrm{~N}$ (or fractional factorial) for $\mathrm{N}$ factors combined with axial or star runs, $\mathrm{ns}=2 \mathrm{~N}$ and centre runs, nc. For the design to be rotatable, axial runs are located at a distance $\pm \alpha$, in a way that $\alpha=[\mathrm{nf}=2 \mathrm{~N}] 1 / 4$ and $|\alpha|>1$. Where $\alpha$ is the distance of the star runs from the centre.

First of all three independent input variables; weld current (I), arc voltage (V) and welding speed (S) were chosen according to their impact on weld characteristics. Pilot study runs were conducted to determine the lower and higher limits of these parameters by one parameter at a time method.

Table 1 represents the different selected variables with their symbols, levels, units.

Table 1: SAW input variables and their levels

\begin{tabular}{|c|c|c|c|c|c|c|}
\hline \multirow[t]{2}{*}{ Process Variables } & \multirow[t]{2}{*}{ Units } & \multicolumn{5}{|c|}{ Levels of Variables } \\
\hline & & -1.682 & -1 & $\mathbf{0}$ & +1 & +1.682 \\
\hline Welding Current, I & A & 311.0 & 340.0 & 382.5 & 425.0 & 454.0 \\
\hline Arc Voltage, $\mathrm{V}$ & $\mathrm{V}$ & 26.0 & 28.0 & 31.0 & 34.0 & 36.0 \\
\hline Weld Speed, S & $\mathrm{m} / \mathrm{h}$ & 22.6 & 25.2 & 29.0 & 32.8 & 35.4 \\
\hline
\end{tabular}

Performing welding: Flat surfaces of high-strength low-alloy steel plates (dimensions $150 \times 150 \times 13 \mathrm{~mm}$ ) were cleaned and welded by taking beads with $3.15 \mathrm{~mm}$ diameter electrode (EH-14). SAW machine (ADOR Tornado SAW M-800) was 
used to take beads with DC electrode-positive polarity (DCEP) keeping nozzle to plate distance constant at $25 \mathrm{~mm}$ for all twenty beads.

Measurement of output responses: Common metallurgical polishing operations were performed on submerged arc welded specimens by sectioning them transversely to observe the bead profiles using $5 \%$ Nital solution as etchant. AxioVision Image Analysing Software was used to analyze the weld profile parameters; reinforcement area (RA), penetration area (PA) (Refer Fig.1). An important weld bead parameter; dilution [1], [6], [10] can be calculated from values of reinforcement area (RA) and penetration area (PA) by using the formulae:

$$
\text { Dilution }=\frac{\text { Penetration Area }}{\text { Penetration Area }+ \text { Reinforcement Area }}
$$

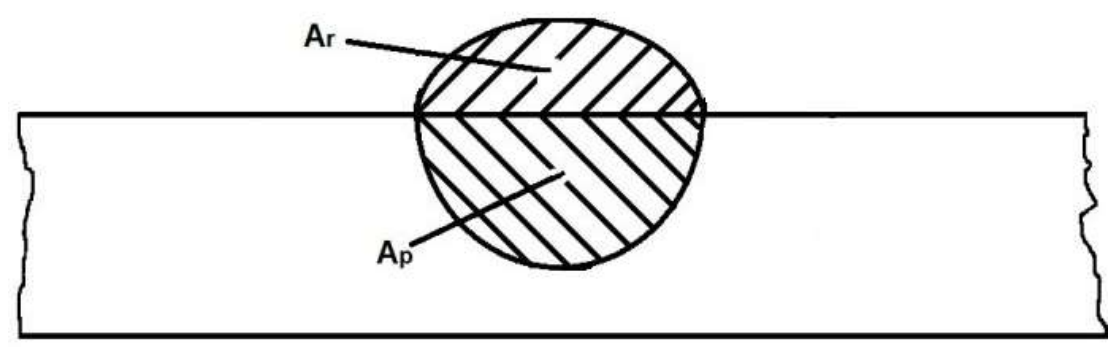

Figure 1: Weld bead profile, RA- reinforcement area, PA- penetration area

\section{RESULTS}

Experimental values of the bead profile responses; reinforcement area (RA), penetration area (PA) and dilution have been represented in the Table 2.

Development of mathematical models: Prediction equations were established for the bead profile characteristics in terms of input welding variables determined from experimentation. Quadratic prediction equations are formed and expressed in the form of process variables; weld current $\mathrm{I}$, arc voltage $\mathrm{V}$ and welding speed $\mathrm{S}$ as:

$$
x=a_{0}+a_{1} I+a_{2} V+a_{3} S+a_{11} I^{2}+a_{22} V^{2}+a_{33} S^{2}+a_{12} I V+a_{13} I S+a_{23} V S
$$

The regression coefficients; $a_{0}, a_{1}, a_{2}, a_{3}, a_{11}, a_{22}, a_{33}, a_{12}, a_{13}, a_{23}$ of the above equation are determined from the experimental data as represented in Table 2 and the prediction equations for the bead profile parameters as a function of input welding variables were formulated and are presented below:

Reinforcement Area, RA $=484.15728+0.77838 \mathrm{I}-25.18789 \mathrm{~V}-13.84751 \mathrm{~S}-0.01029 \mathrm{I}^{2}-0.01633 \mathrm{~V}^{2}+0.15022 \mathrm{~S}^{2}$ $+0.00004 \mathrm{IV}+0.40332 \mathrm{IS}+0.24036 \mathrm{VS}$

Penetration Area, $\mathrm{PA}=1348.88113+0.18722 \mathrm{I}-72.55289 \mathrm{~V}-16.04391 \mathrm{~S}+0.02118 \mathrm{I} 2-0.03514 \mathrm{~V} 2+0.17105 \mathrm{~S} 2$ $+0.00040 \mathrm{IV}+1.00970 \mathrm{IS}+0.35448 \mathrm{VS}$

Dilution $=2.982380-0.005309 \mathrm{I}-0.107315 \mathrm{~V}+0.011745 \mathrm{~S}+0.000157 \mathrm{I}^{2}-0.000015 \mathrm{~V}^{2}+0.000439 \mathrm{~S}^{2}+0.000002 \mathrm{IV}$ $+0.000720 \mathrm{IS}-0.000408 \mathrm{VS}$ 
Table 2: Design table indicating input variables and output responses

\begin{tabular}{|c|c|c|c|c|c|c|}
\hline Run & $\begin{array}{c}\text { Weld } \\
\text { Current I } \\
\text { (A) }\end{array}$ & $\begin{array}{c}\text { Arc } \\
\text { Voltage V } \\
\text { (V) }\end{array}$ & $\begin{array}{l}\text { Welding } \\
\text { Speed } \\
\text { S (m/hr) }\end{array}$ & $\begin{array}{l}\text { Reinforcement Area } \\
\text { RA }\left(\mathrm{mm}^{2}\right)\end{array}$ & $\begin{array}{l}\text { Penetration Area } \\
\qquad \text { PA }\left(\mathrm{mm}^{2}\right)\end{array}$ & Dilution \\
\hline 1 & 340.0 & 28.0 & 25.2 & 38.0 & 61.8 & 0.62 \\
\hline 2 & 425.0 & 28.0 & 25.2 & 45.2 & 77.6 & 0.63 \\
\hline 3 & 340.0 & 34.0 & 25.2 & 36.0 & 68.2 & 0.65 \\
\hline 4 & 425.0 & 34.0 & 25.2 & 42.0 & 98.9 & 0.70 \\
\hline 5 & 340.0 & 28.0 & 32.8 & 26.1 & 38.9 & 0.60 \\
\hline 6 & 425.0 & 28.0 & 32.8 & 26.8 & 36.1 & 0.57 \\
\hline 7 & 340.0 & 34.0 & 32.8 & 35.0 & 57.2 & 0.62 \\
\hline 8 & 425.0 & 34.0 & 32.8 & 26.4 & 61.1 & 0.70 \\
\hline 9 & 311.0 & 31.0 & 29.0 & 25.9 & 41.9 & 0.62 \\
\hline 10 & 454.0 & 31.0 & 29.0 & 29.0 & 57.9 & 0.67 \\
\hline 11 & 382.5 & 26.0 & 29.0 & 35.6 & 56.8 & 0.61 \\
\hline 12 & 382.5 & 36.0 & 29.0 & 39.4 & 90.3 & 0.70 \\
\hline 13 & 382.5 & 31.0 & 22.6 & 46.2 & 84.6 & 0.65 \\
\hline 14 & 382.5 & 31.0 & 35.4 & 27.9 & 40.1 & 0.59 \\
\hline 15 & 382.5 & 31.0 & 29.0 & 26.9 & 48.1 & 0.64 \\
\hline 16 & 382.5 & 31.0 & 29.0 & 27.0 & 46.0 & 0.63 \\
\hline 17 & 382.5 & 31.0 & 29.0 & 28.3 & 49.1 & 0.63 \\
\hline 18 & 382.5 & 31.0 & 29.0 & 27.9 & 47.1 & 0.63 \\
\hline 19 & 382.5 & 31.0 & 29.0 & 27.3 & 48.5 & 0.64 \\
\hline 20 & 382.5 & 31.0 & 29.0 & 26.1 & 47.2 & 0.64 \\
\hline
\end{tabular}

Significance testing of model: It can be seen from of Fig. 3 that all the experimentally determined values are in good agreement with the predicted values and making the model correct. Analysis of variance of all predicted models is done and found to be significant at $95 \%$ confidence level. 


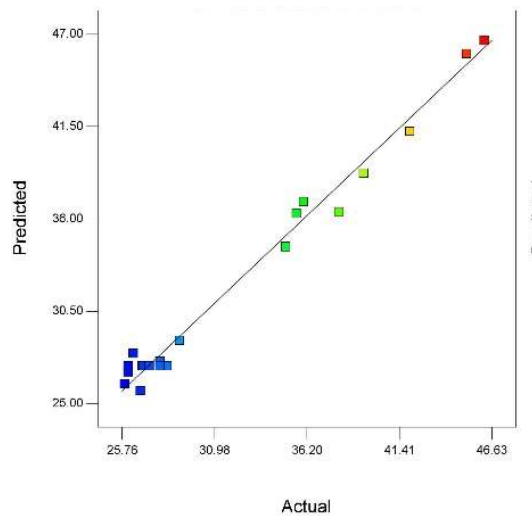

(a)

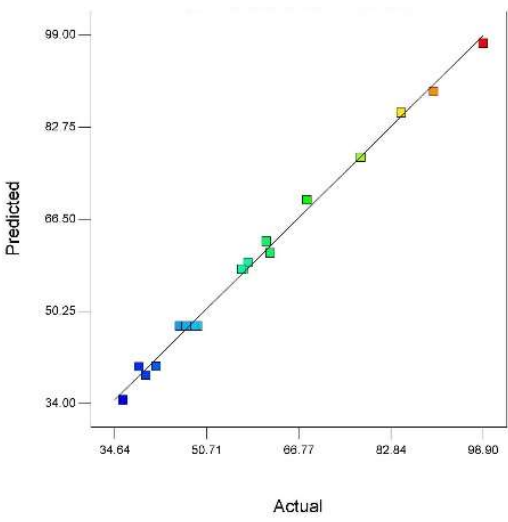

(b)

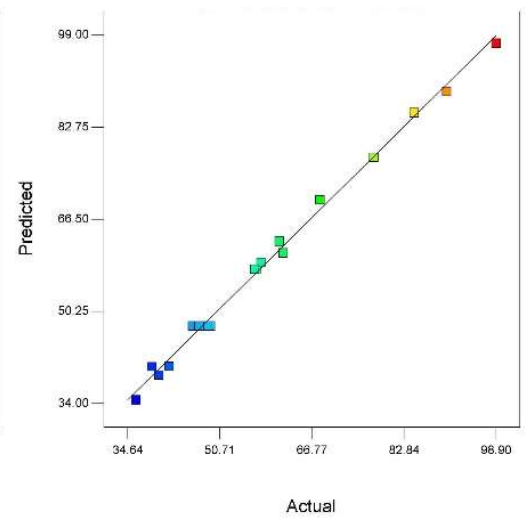

(c)

Figure 2: Predicted versus actual values for (a) Reinforcement Area (b) Penetration Area (c) Dilution

\section{DISCUSSIONS}

Direct Effect of Welding Variables on Weld Bead Profile

\begin{tabular}{|c|c|c|c|c|c|c|c|}
\hline Variable & Term & $\begin{array}{l}\text { Sum of } \\
\text { Squares }\end{array}$ & DOF & F-Test & Probability & $\mathbf{R}^{2}$ & $\begin{array}{c}\text { Significance of } \\
\text { model }\end{array}$ \\
\hline \multirow{12}{*}{$\begin{array}{c}\text { Reinforcement Area, } \\
\text { RA }\end{array}$} & Model & 885.03 & 9 & 71.49 & 0.0001 & 0.985 & \multirow{12}{*}{ Adequate } \\
\hline & I & 8.09 & 1 & 5.88 & 0.0357 & & \\
\hline & $\mathrm{V}$ & 6.88 & 1 & 5.00 & 0.0494 & & \\
\hline & $\mathrm{S}$ & 441.81 & 1 & 321.18 & 0.0001 & & \\
\hline & IV & 13.78 & 1 & 10.02 & 0.0101 & & \\
\hline & IS & 55.65 & 1 & 40.46 & 0.0001 & & \\
\hline & VS & 23.46 & 1 & 17.06 & 0.0020 & & \\
\hline & $\mathrm{I}^{2}$ & 0.0846 & 1 & 0.0615 & 0.8091 & & \\
\hline & $\mathrm{V}^{2}$ & 189.88 & 1 & 138.04 & 0.0001 & & \\
\hline & $\mathrm{S}^{2}$ & 173.60 & 1 & 126.20 & 0.0001 & & \\
\hline & $\begin{array}{l}\text { Lack of } \\
\text { Fit }\end{array}$ & 10.72 & 5 & 3.53 & 0.0962 & & \\
\hline & Pure Error & 3.03 & 5 & & & & \\
\hline \multirow{12}{*}{$\begin{array}{c}\text { Penetration Area } \\
\text { PA }\end{array}$} & Model & 5981.54 & 9 & 248.87 & 0.0001 & 0.996 & \multirow{12}{*}{ Adequate } \\
\hline & I & 405.95 & 1 & 152.01 & 0.0001 & & \\
\hline & $\mathrm{V}$ & 1187.98 & 1 & 444.85 & 0.0001 & & \\
\hline & $\mathrm{S}$ & 2587.71 & 1 & 968.98 & 0.0001 & & \\
\hline & IV & 58.32 & 1 & 21.84 & 0.0009 & & \\
\hline & IS & 257.65 & 1 & 96.48 & 0.0001 & & \\
\hline & VS & 30.42 & 1 & 11.39 & 0.0071 & & \\
\hline & $\mathrm{I}^{2}$ & 7.41 & 1 & 2.77 & 0.1268 & & \\
\hline & $\mathrm{V}^{2}$ & 1190.07 & 1 & 445.63 & 0.0001 & & \\
\hline & $\mathrm{S}^{2}$ & 377.58 & 1 & 141.39 & 0.0001 & & \\
\hline & $\begin{array}{l}\text { Lack of } \\
\text { Fit }\end{array}$ & 5981.54 & 5 & 3.18 & 0.1151 & & \\
\hline & Pure Error & 405.95 & 5 & & & & \\
\hline \multirow{7}{*}{ Dilution } & Model & 0.0238 & 9 & 34.76 & 0.0001 & 0.979 & \multirow{7}{*}{ Adequate } \\
\hline & I & 0.0030 & 1 & 40.07 & 0.0001 & & \\
\hline & $\mathrm{V}$ & 0.0124 & 1 & 162.79 & 0.0001 & & \\
\hline & $\mathrm{S}$ & 0.0036 & 1 & 46.95 & 0.0001 & & \\
\hline & IV & 0.0032 & 1 & 42.04 & 0.0001 & & \\
\hline & IS & 0.0001 & 1 & 0.6569 & 0.4365 & & \\
\hline & VS & 0.0002 & 1 & 2.63 & 0.1361 & & \\
\hline
\end{tabular}




\begin{tabular}{|c|c|c|c|c|c|c|c|}
\hline \multirow{4}{*}{} & $\mathrm{I}^{2}$ & 0.0001 & 1 & 1.64 & 0.2291 & & \\
\cline { 2 - 7 } & $\mathrm{V}^{2}$ & 0.0006 & 1 & 7.95 & 0.0182 & \\
\cline { 2 - 7 } & $\mathrm{S}^{2}$ & 0.0005 & 1 & 6.58 & 0.0281 & \\
\cline { 2 - 8 } & $\begin{array}{c}\text { Lack of } \\
\text { Fit }\end{array}$ & 0.0006 & 10 & & & \\
\cline { 2 - 8 } & Pure Error & 0.0002 & 5 & 4.07 & 0.0747 & & \\
\hline
\end{tabular}

Effect of welding current on Reinforcement Area, Penetration Area and dilution: Dilution increases linearly with the increase in welding current from $311 \mathrm{~A}$ to $454 \mathrm{~A}$ as observed from Fig. 3a. But dilution further depends on values of reinforcement area (RA) and penetration area (PA). Since increase of PA is more steep than increase in RA for all values of welding current (Fig. 4b); phenomenon for the increase in these responses may be explained as heat input ( $\left.\mathrm{I}^{2} \mathrm{Rt}\right)$ in welding increases with current which increases the more of base metal to melt and to penetrate deeply due to increase in heat content and thrust of the weld arc thereby finally getting relatively more increase in Penetration Area than Reinforcement Area (Refer Fig 3b).

Effect of arc voltage on Reinforcement Area, Penetration Area and dilution: There is sharp increase in dilution as weld voltage increases from $26 \mathrm{~V}$ (lowest level) to $36 \mathrm{~V}$ (highest level) as seen in (Fig. 4a). Increase in PA is more steeper than increase in RA throughout whole voltage range. Since weld cone increases with an increase in voltage which further increases molten pool area in the plate but increase in reinforcement area, RA is relatively less thereby increasing dilution.

Effect of welding speed on dilution: Dilution decreases with the increase in speed for all values (Fig. 5a). With the increase in welding speed from $22.6 \mathrm{~m} / \mathrm{hr}$ to $35 \mathrm{~m} / \mathrm{hr}$ both the areas of reinforcement and penetration decreases slowly (Fig. 5b) thereby decreasing dilution.

Table 3: ANOVA for Reinforcement Area, Penetration Area, Dilution

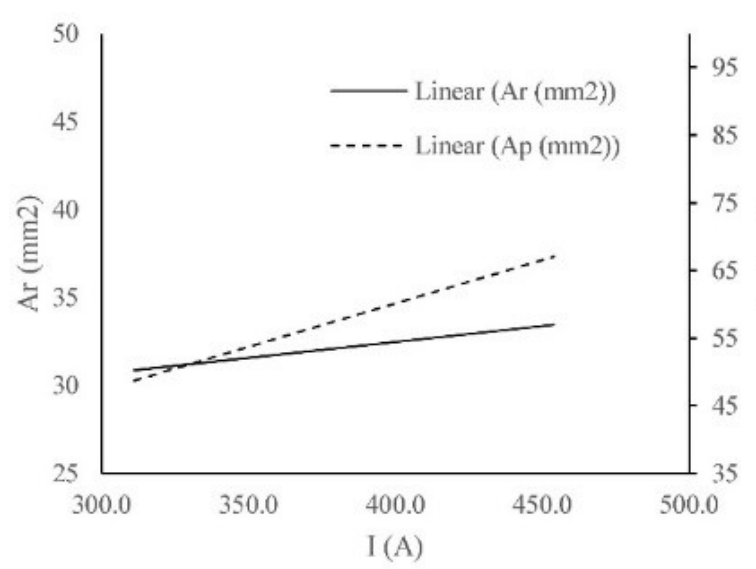

(a)

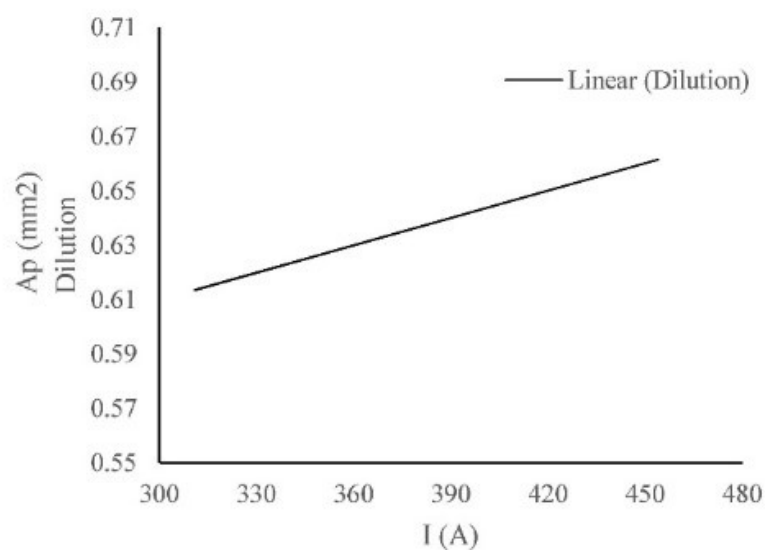

(b)

Figure 3: Effect of Welding Current on (a) Reinforcement Area (RA), Penetration Area (PA) (b) Dilution 


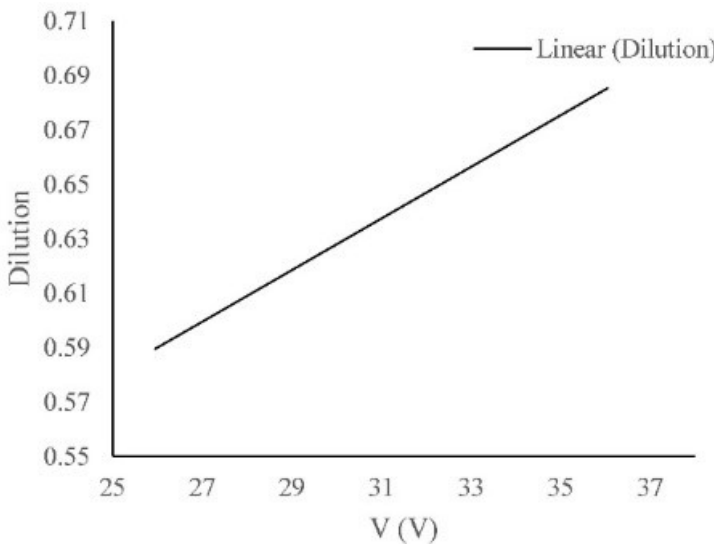

(a)

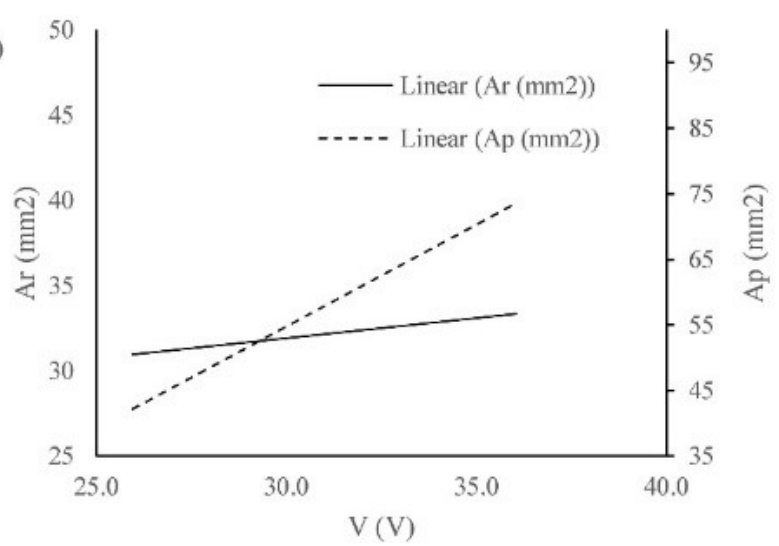

(b)

Figure 4: Effect of Arc Voltage on (a) Reinforcement Area (RA), Penetration Area (PA) (b) Dilution

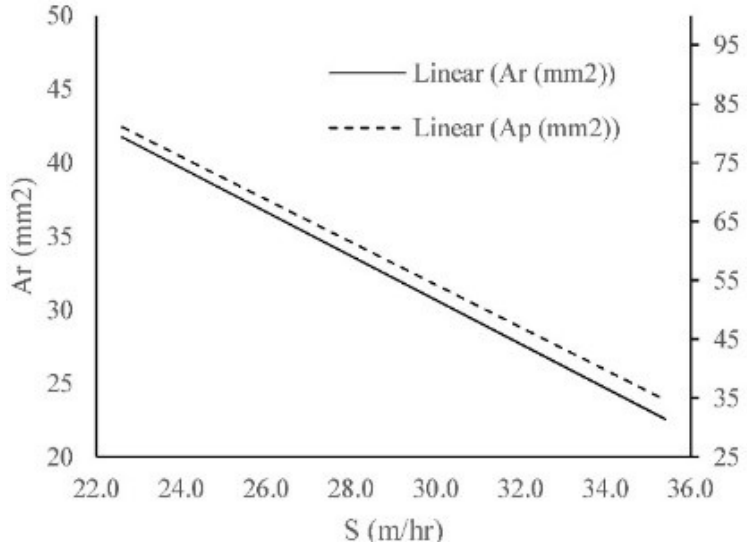

(a)

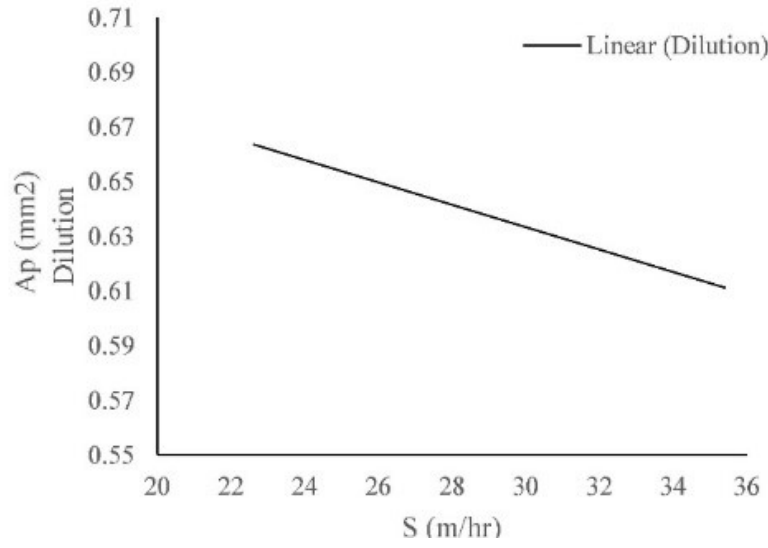

(b)

Figure 5: Effect of Welding Speed on (a) Reinforcement Area (RA), Penetration Area (PA) (b) Dilution

\section{COMBINED EFFECT OF WELDING PARAMETERS}

Combined effect of welding parameters on reinforcement area: Response surface plot (Fig. 6a) indicates that there is significant interaction among weld current and arc voltage; as at the lowest value (28V) of arc voltage, RA increases with increase in value of current from 340A to 425A but opposite trend is observed at the highest level (34V) of voltage. Similar variation of RA is being observed with increase/decrease in arc voltage is different at lowest and highest levels of welding current.

Similar trend among factors; current and speed can be seen from the interaction plot between welding current and weld speed for RA (Refer Fig. 6b). Hence the interaction among welding current and weld speed can be easily understood.

3D surface plot showing interaction among voltage and speed for RA (Refer Fig. 6c) represents significant interaction between input parameters. The plot indicates that value of RA at the lowest value of arc voltage (28V) decreases slightly with increase in speed but slight opposite trend is being observed at the highest level of voltage (34V) there hence indicating interaction between input parameters.

Combined effect of welding parameters on penetration area: Surface plot (Fig. 7a) for Penetration Area (PA) between 
current and voltage is slightly significant; as PA remains almost constant with increase of current at the lowest value (28V) of arc voltage but PA increases linearly with an increase in welding current at the highest value (34V) of arc voltage.

In the same manner welding current and weld speed shows interaction between them as Penetration Area increases linearly and sharply at the minimum value of weld speed but remains almost constant with increase in welding current value at the maximum value of weld speed (Refer Fig. 7b).

Response surface plot between arc voltage and weld speed for PA is represented in Fig. 7c. Surface plot shows that PA decreases gradually and constantly with speed at the lowest value of arc voltage (28V) but this decrease is sharper with increase in speed at the highest value of arc voltage $(34 \mathrm{~V})$ hence indicating significant interaction among factors

Combined effect of welding parameters on dilution: Response surface graph (Fig. 8a) represents most significant interaction among welding current and arc voltage for dilution; since dilution decreases slightly with increase in welding current from $340 \mathrm{~A}$ to $425 \mathrm{~A}$ at the lowest level of arc voltage (-1.682 value) but increases sharply with same current increase values at the highest value ( +1.682 value) of voltage. Also dilution increases slightly at the lowest level of current but increases much sharply at the highest level of welding current with increase in arc voltage for whole range.

Plot (Fig. 8b) shows small interaction between voltage and weld speed for the said reasons and explanation and similarly Fig. 8c represents some interaction between welding current and weld speed.

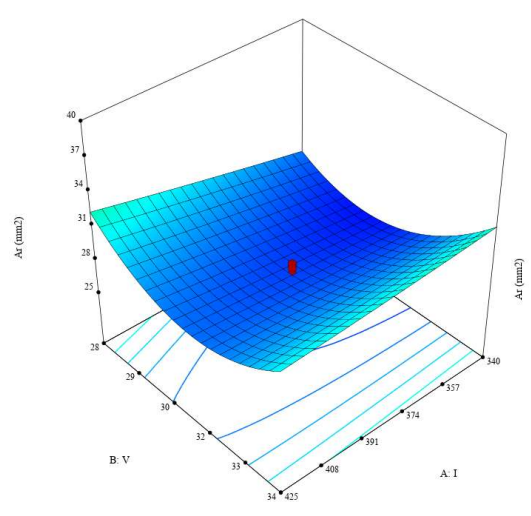

(a)

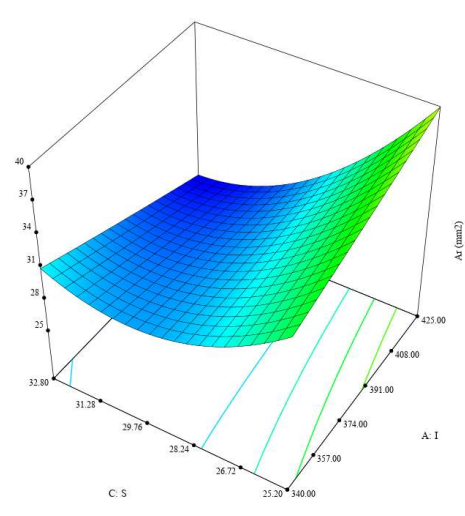

(b)

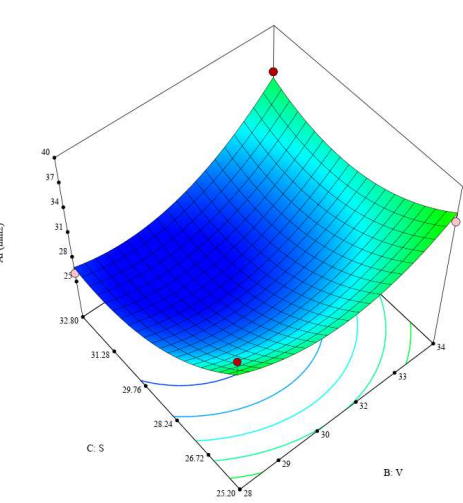

(c)

Figure 6: combined effect of (a) welding current and weld speed (b) welding current and voltage (c) arc voltage and weld speed on Reinforcement Area (RA)

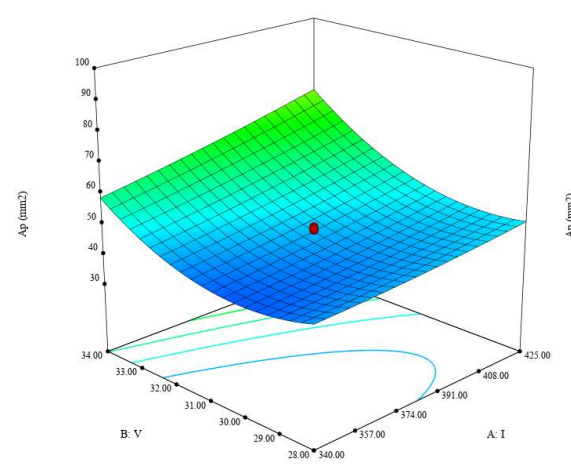

(a)

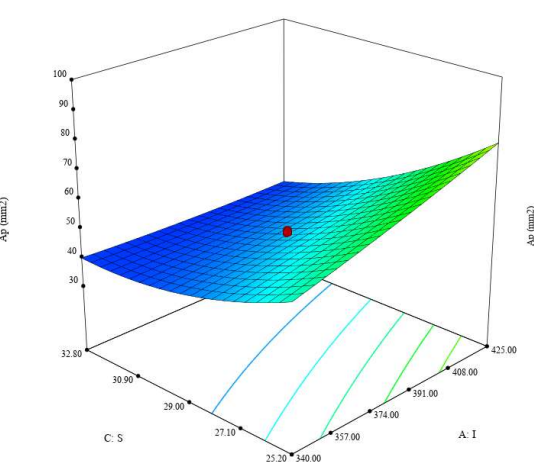

(b)

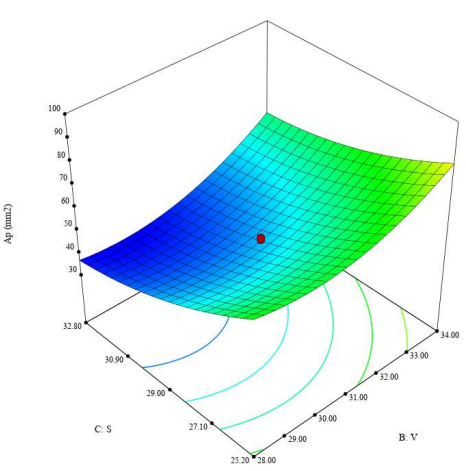

(c)

Figure 7: combined effect of (a) welding current and arc voltage (b) welding current and weld speed (c) weld speed 


\section{and arc voltage on Penetration Area (PA)}

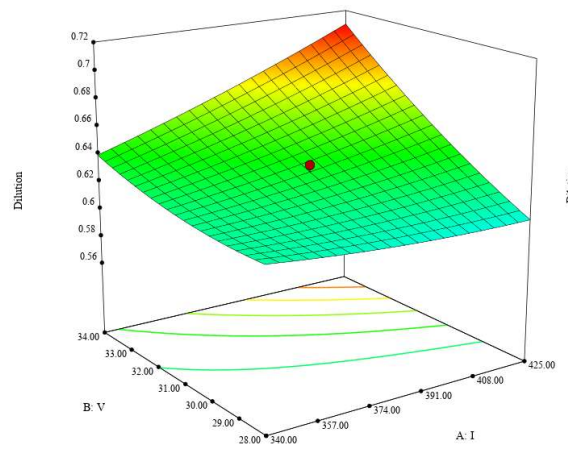

(a)

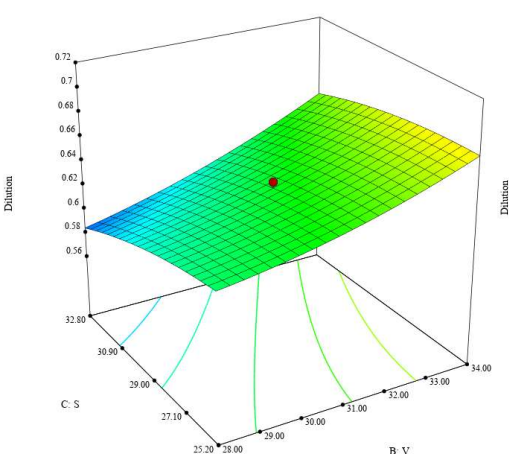

(b)

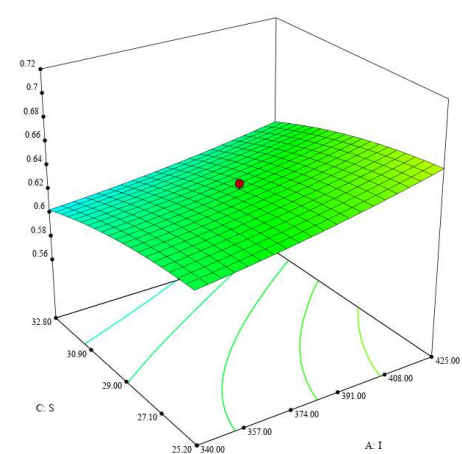

(c)

Figure 8: combined effect of (a) welding current and arc voltage (b) welding current and weld speed (c) weld speed and arc voltage on dilution

\section{CONCLUSIONS}

- The present work developed prediction equations for weld bead geometry profile which can be readily used for similar materials and applications.

- Arc voltage is the most significant effect but welding speed is less significant among three input weld bead parameters.

- Predicted vs Actual plots indicate close agreement between model predicted values and experimentally determined values showing prediction models are significant.

- $\quad$ Significant interaction can be judged from the response surface plots

\section{ACKNOWLEDGEMENTS}

Authors received no financial assistance from any agency to carry out this research work .

\section{REFERENCES}

1. Houldcroft PT (1989). Submerged Arc Welding. $2^{\text {nd }}$ ed. England: Abington Publishing.

2. Chandar Rathod \& Gondi Konda Reddy, "Experimental Investigation of Angular Distortion and Transverse Shrinkage in Co2 Arc Welding Process “, International Journal of Mechanical Engineering (IJME), Vol. 5, Issue 4,pp. 21-28

3. Murugan N and Gunaraj V (2005). Prediction and control of weld bead geometry and shape relationships in submerged arc welding of pipes, (pp. 478-487) J. of Mat. Proc. Technol.

4. Parmar RS (1992). Welding Processes and Technology, New Delhi: Khanna Publishers.

5. Chai CS, Eagar TW (1980). The effect of SAW parameters on weld metal chemistry, (pp. 93-98). Welding Research Supplement.

6. Prasad K, Dwivedi DK (2008). Some investigations on microstructure and mechanical properties of submerged arc welded HSLA steel joints, (pp. 475-483) Int. J. Adv. Manuf. Technol. 
7. I. U. Abhulimen \& J. I. Achebo, "The Use of Adaptive Neuro Fuzzy Inference System (ANFIS) in Modeling the Weld Output of a TIG Welded Pipe Joint “, IMPACT: International Journal of Research in Engineering \& Technology (IMPACT: IJRET), Vol. 2, Issue 9, pp. 99-110

8. Murugan N, Gunaraj V (1999). Application of response surface methodology for predicting weld bead quality in submerged arc welding of pipes, (pp. 266-275) Journal of Materials Processing Technology.

9. Singh B, Khan ZA, Siddiquee AN, Maheshwari S (2016). Effect of CaF2, FeMn and NiO additions on Impact Strength and Hardness in Submerged Arc Welding Using Developed Agglomerated Fluxes, (pp. 158-169) Journal of Alloys and Compounds.

10. K. E. Ch. Vidya Shekar \& R. K. Sharma, "Improvement of Power Quality in an a Induction Generator Based Wind Power Generating System Connected to Grid by Using UPFC “, International Journal of Electrical and Electronics Engineering (IJEEE), Vol. 3, Issue 3, pp. 1-10

11. Innocent Uduehi Abhulimen, "Evaluation of the Hardness and Microstructure of a Tungsten Inert Gas Weld of a Mild Steel Pipe Joint ", IMPACT: International Journal of Research in Engineering \& Technology (IMPACT: IJRET), Vol. 2, Issue 8, pp. 117-126

12. Yadav A, Ghosh A, Kumar A (2017). Experimental and numerical study of thermal field and weld bead characteristics in submerged arc welded plate. Journal of Materials Processing Tech. (pp. 262-274).

13. Lee CS, Chandel RS, Seow HP (2000). Effect of welding parameters on the size of heat affected zone of submerged arc welding. Materials and Manufacturing Processes (pp. 649-666).

14. O'Brien A, Guzman C (2004). Welding Handbook: Welding Processes, Part 2. Miami (FL): American Welding Society.

15. Montgomery DC (2008). Design and analysis of experiments. New York, Wiley.

16. Montgomery DC, Runger GC (2010). Applied Statistics and Probability for Engineers. John Wiley \& Sons. 